\title{
IMPLICATIONS OF CLIMATE CHANGE FOR WESTERN CONCEPTS OF OWNERSHIP: AUSTRALIAN CASE STUDY
}

\author{
VANESSA JOHNSTON* AND BEN FRANCE-HUDSON**
}

\begin{abstract}
This article considers what Australian responses to climate change may teach us about the concept of ownership. Through a close analysis of laws aimed at encouraging specific land uses in order to mitigate emissions, it argues that these laws support the increasingly uncontroversial claim that ownership of estates or interests in land places obligations and responsibilities on owners to exercise the resulting rights for the benefit of others. However, although land ownership is flexible enough to support the environmental objectives of these laws, their failure to adequately accommodate the practicalities of ownership, such as anticipating the position of successors in title, increases the risk of conflict between owners of estates and interests in land, and compromises the ability of both environmental and property law regimes to achieve their intended objectives.
\end{abstract}

\section{INTRODUCTION}

As Australia responds to climate change by attempting to mitigate greenhouse gas ('GHG') emissions, and starts the process of adapting to changing environmental conditions, laws and regulations that encourage or require action in this sphere are engaging with aspects of what it means to own something. Importantly, the tools adopted by the Commonwealth and State or Territory governments are challenging the ostensibly settled view of ownership held by many people in Australia and other Western liberal democracies: that the overarching goal of private property as an institution is to allow individuals to use property to achieve their own goals regarding that which they own, and by so doing increase aggregate social wealth. ${ }^{1}$ As Carol Rose notes, on this account, private

\footnotetext{
* Vanessa Johnston is a Lecturer at Monash University, Clayton, Victoria, Australia.

** Ben France-Hudson is a Senior Lecturer at the University of Otago, Dunedin, New Zealand. The authors would like to thank the anonymous reviewers for their helpful comments.

1 Joan Williams, 'The Rhetoric of Property' (1998) 83(2) Iowa Law Review 277, 300. Cf Anna Di Robilant, 'Property and Democratic Deliberation: The Numerus Clausus Principle and Democratic Experimentalism in Property Law’ (2014) 62(2) American Journal of Comparative Law 367, 403.
} 
property is about 'preference satisfaction'. ${ }^{2}$ These tools also confront the view that the role of government in property matters should be minimal. ${ }^{3}$ While in this regard, private property describes the property of private citizens, rather than that which is owned by the state, private property is not, and never has been, a 'sole and despotic dominion' ${ }^{4}$ within which an owner can do as they please. Rather, private property operates within a regulatory framework that imposes boundaries on the nature of real and personal property that can be owned by private citizens, and the rights and duties that arise from such ownership. ${ }^{5}$

Climate change challenges the boundaries of this framework in both respects. New forms of personal chose in action have been created by statute in order to encourage entities to implement projects to reduce or avoid GHG emissions. ${ }^{6}$ Where emissions reduction or avoidance projects are implemented on a specific parcel of land, statutory schemes may also restrict how rights of use, enjoyment, or alienation are exercised by relevant estate or interest holders. While the creation of new forms of personal property is perhaps how people most commonly connect property and ownership with climate change, the restrictions that climate change regulations can place on ownership of real property illustrates the social and flexible nature of private property in relation to community interests. This observation reinforces the increasingly uncontroversial understanding that rights arising from land ownership involve obligations based on the relationship that an owner has with other individuals and the community.

Not only does this challenge the view that, in the context of Western liberal property theory, ownership in relation to land has an ostensibly settled meaning, but on the basis of this powerful observation, a dichotomy emerges. Existing private property regimes can be self-consciously amended to achieve desired environmental outcomes (such as the creation of new types of chose in action), without needing to turn to something completely new. ${ }^{7}$ However, care must be taken to consider the consequences of such amendments for ownership of other things, such as land. If care is not taken, inconsistencies can arise that threaten to undermine the integrity of both environmental and property law regimes, and in the present case, contribute to increased conflict between owners of estates and interests in land. Ultimately, such conflicts may operate to threaten the success of the regimes adopted to meet the challenges of climate change.

2 Carol M Rose, Property and Persuasion: Essays on the History, Theory, and Rhetoric of Ownership (Westview Press, 1994) 52.

3 Carol M Rose, 'Privatization: The Road to Democracy' (2006) 50(3) Saint Louis University Law Journal 691,702 .

4 William Blackstone, Commentaries on the Laws of England: Book the Second (Dawsons of Pall Mall, 1966) vol 2, 2. William Blackstone also wrote that 'the law of the land ... [postponed] even public necessity to the sacred and inviolable rights of private property': William Blackstone, Commentaries on the Laws of England: Book the First (Dawsons of Pall Mall, 1966) vol 1, 135.

5 See Yanner v Eaton (1999) 201 CLR 351, 365-7 (Gleeson CJ, Gaudron, Kirby and Hayne JJ).

6 JH Dales, Pollution, Property \& Prices: An Essay in Policy-Making and Economics (University of Toronto Press, 1968) 77, 99.

7 See Ben France-Hudson, 'Surprisingly Social: Private Property and Environmental Management' (2017) 29(1) Journal of Environmental Law 101 ('Surprisingly Social'). 
Responses to climate change, particularly those that affect land directly, provide a key example through which to explore and illustrate how countertraditions based on obligation and responsibility can operate within the existing Western liberal tradition. Obligations arise in respect of climate change due to commitments made by countries at international and domestic levels to mitigate GHG emissions in order to slow global warming that will have a range of potentially catastrophic impacts for both natural and built environments worldwide. ${ }^{8}$ Indeed, these effects are already being felt. ${ }^{9}$ Pursuant to the 2015 Paris Agreement,$^{10}$ participating countries agreed to reduce $\mathrm{GHG}$ emissions to levels that should stabilise the increase of global average temperatures to no more than $2{ }^{\circ} \mathrm{C}$ above pre-industrial levels, but pursuing efforts to limit the temperature increase to within $1.5^{\circ} \mathrm{C}$ of that range..$^{11}$ Australia's contribution to this target is to reduce GHG emissions by $26-28 \%$ below 2005 levels by $2030 .{ }^{12}$

In order to achieve this target, Australia has enacted a range of laws that encourage mitigation of GHG emissions, including the flagship national Emissions Reduction Fund ('ERF') established by the Carbon Credits (Carbon Farming Initiative) Act 2011 (Cth) ('Carbon Credits Act'). ${ }^{13}$ The Carbon Credits Act affects private property in Australia in two key ways. First, it recognises a 'carbon credit' relating to GHG emissions mitigation or avoidance as a form of personal property, which can be purchased and sold according to the terms of the Carbon Credits $A c t .{ }^{14}$ Second, the carbon credit is often created or surrendered in relation to GHG emissions mitigation or avoidance projects implemented on private land. While carbon credits may be created under the Carbon Credits Act from activities across all economic sectors, to date most have arisen from agricultural and forestry activities that occur on specific parcels of land, including avoidance of landclearing and deforestation, or the sequestration of carbon in soil or vegetation by way of permanent plantings, revegetation, and reforestation. ${ }^{15}$ In this regard, while

8 Intergovernmental Panel on Climate Change, Climate Change 2014 (Synthesis Report, 2015) 102-6.

9 Ibid. See further Australian Government, National Climate Resilience and Adaptation Strategy (Report, 2015); Australian Government, Climate Change in Australia: Projections for Australia's NRM Regions (Cluster Reports, 2015) <https://www.climatechangeinaustralia.gov.au/en/publications-library/clusterreports $>$, regarding the impact of climate change in Australia by region.

10 Adoption of the Paris Agreement, CP.21, $21^{\text {st }}$ sess, Agenda Item 4(b), UN Doc FCCC/CP/2015/L.9/Rev.1 (12 December 2015) annex ('Paris Agreement').

11 Paris Agreement, UN Doc FCCC/CP/2015/L.9/Rev.1 (n 10) art 2(1).

12 Commonwealth of Australia, Australia's Intended Nationally Determined Contribution to a New Climate Change Agreement (August 2015)

$<$ https://www4.unfecc.int/sites/submissions/indc/Submission\%20Pages/submissions.aspx >.

13 Carbon Credits (Carbon Farming Initiative) Act 2011 (Cth) ss 3(2), (3), (5), 4; Liberal Party of Australia and Nationals, 'The Coalition's Direct Action Plan: Environment \& Climate Change' (1 August 2010) 1.

14 Carbon Credits Act s 150.

15 Projects must be implemented according to 'methodology determinations' relevant to the project activity: ibid s 27(4)(b). These include Carbon Credits (Carbon Farming Initiative) (Reforestation by Environmental or Mallee Plantings) Methodology Determination 2014 (Cth); Carbon Credits (Carbon Farming Initiative - Reforestation and Afforestation 2.0) Methodology Determination 2015 (Cth); Carbon Credits (Carbon Farming Initiative) (Native Forest from Managed Regrowth) Methodology Determination 2013 (Cth); Carbon Credits (Carbon Farming Initiative) (Human-Induced Regeneration of a Permanent Even-Aged Native Forest - 1.1) Methodology Determination 2013 (Cth); Carbon Credits (Carbon Farming Initiative - Avoided Clearing of Native Regrowth) Methodology Determination 2015 
the primary objective of the Carbon Credits Act is to encourage mitigation or avoidance of GHG emissions, rather than change how land may be used or the concepts or laws that affect land ownership, it may affect land use and property in both of these ways by incentivising land-based GHG emissions mitigation activities. According to the Australian Bureau of Agricultural and Resource Economics and Sciences, approximately $60 \%$ of Australia's land mass is used for agricultural or forestry purposes. ${ }^{16}$ This statistic suggests that there is significant scope for privately-owned land to be voluntarily brought within the scope of the Carbon Credits Act. In fact, more than 500 agricultural or forestry projects have been implemented to date, ${ }^{17}$ which indicates that landowners are subjecting their land, and with it their ownership rights, to possible restrictions imposed by the Carbon Credits Act. Moreover, carbon sequestration activities, such as planting and reforestation, are also encouraged by State forestry laws, and as a by-product of land conservation activities implemented under laws that promote environmental protection and biodiversity conservation. In this context, landbased mitigation efforts are likely to form a very large part of Australia's efforts to meet international commitments as translated into specific targets within domestic laws, and also more general goals to reduce GHG emissions in an effort to stave off the most severe effects of climate change. While implementing a project on specific land to mitigate or avoid GHG emissions under the Carbon Credits Act may be voluntary, the consequences of doing so for land ownership, for both current and future owners, are not. The possibility that these consequences will impact land ownership by successors in title can only increase as more land is brought under the Carbon Credits Act by virtue of its use in ERF projects.

Recognising that private property (land, in this case) can serve both individual and community needs, and confer rights and obligations, is crucial to the development of effective climate change and real property regimes. In this article, we argue that, while there is evidence of these ideas at work within Australia's responses to climate change, greater consideration needs to be given to the property law consequences of these regimes during their design and development. Similarly, consideration should be given to how property law can better accommodate Australia's response to climate change. The article begins by outlining the competing accounts of land ownership under the Western tradition before then considering the way that Australia's current responses to climate change reflect the existence of social obligations that are inherent to land ownership, which are becoming increasingly apparent in this context. It then critically discusses the challenges that Australia's responses to climate change

(Cth); Carbon Credits (Carbon Farming Initiative) (Sequestering Carbon in Soils in Grazing Systems) Methodology Determination 2014 (Cth). See also 'Opportunities for the Land Sector', Clean Energy Regulator (Web Page, 14 November 2017) <http://www.cleanenergyregulator.gov.au/ERF/Choosing-aproject-type/Opportunities-for-the-land-sector $>$.

16 Australian Collaborative Land Use and Management Program, 'Land Use in Australia: At a Glance', Australian Government Department of Agriculture (Pamphlet, 2016) 4 fig 3

$<$ http://www.agriculture.gov.au/abares/aclump/Documents/Land\%20use \%20in\%20Australia\%20at $\% 20$ a $\% 20$ glance $\% 202016 . p d f>$.

17 'Emissions Reduction Fund Project Map', Clean Energy Regulator (Web Page, 3 August 2017) $<$ http://www.cleanenergyregulator.gov.au/maps/Pages/erf-projects/index.html $>$. 
pose to the practical ways in which people conceive of their ownership of land, their ability to use it as they wish, and the ability to discover the obligations attendant on a piece of land in the context of purchase. Ultimately, although ownership of land can operate to accommodate environmental outcomes, it is critical to first consider how land ownership and title systems operate in Australia before enacting laws to achieve those outcomes that affect land. Doing so will minimise conflict between environmental and real property law regimes, and as between owners of relevant estates and interests in land in the context of climate change, leading to the development of schemes that have the greatest chance of achieving the overarching goal to reduce GHG emissions in an effort to mitigate the untempered consequences of climate change.

\section{CLASSICAL LIBERALISM AND THE COUNTER- TRADITIONS IN WESTERN PROPERTY THEORY}

\section{A The Classical Liberal Account of Ownership of Private Property}

In Australia, the dominant conception of ownership is premised on the classic liberal tradition. On this account, ownership of private property is central to protecting autonomy, and strengthens the market to ensure that aggregate social wealth increases. ${ }^{18}$ Much has been written about the classical liberal idea of ownership, but in summary, its ultimate normative claim is that a social and economic system based on private property which maximises individual preference satisfaction is the best (or only) way to ensure individuals are truly free. ${ }^{19}$ Private property is seen as motivating individuals to husband their resources in their own self-interest. It also makes it clear who owns what; encouraging trade rather than disputes over scarce resources. Through specialisation, everyone gets richer as there is more to go around. ${ }^{20}$ Moreover, private property can be seen as the legal mechanism by which individuals can exercise and enjoy free choice over how they wish to use resources and live their lives, that is, to satisfy their own preference. ${ }^{21}$ Consequently, on this account, private property is seen as central in confining the powers of the state as it demarcates the zone between public and private and insulates the individual from uncompensated expropriation. ${ }^{22}$

A trope that follows this account is that in order to create the best society the rights that accompany private ownership of real or personal property should be absolute. Rights arising from ownership should only be limited by the rights of

18 Williams, 'The Rhetoric of Property' (n 1) 343-56.

19 Emily Sherwin, 'Two- and Three-Dimensional Property Rights' (1997) 29(4) Arizona State Law Journal 1075, 1083.

20 Carol M Rose, 'Property as the Keystone Right?' (1995) 71(3) Notre Dame Law Review 329, 331.

21 Paul Babie, 'Idea, Sovereignty, Eco-Colonialism and the Future: Four Reflections on Private Property and Climate Change' (2010) 19(3) Griffith Law Review 527, 531 ('Idea, Sovereignty, Eco-Colonialism and the Future').

22 Michael Robertson, 'Liberal, Democratic, and Socialist Approaches to the Public Dimensions of Private Property' in Janet McLean (ed), Property and the Constitution (Hart Publishing, 1999) 239, 242. 
others and the public interest in a very restrictive sense (normally restricted to the duty not to harm others). ${ }^{23}$ Charles Reich, for example, noted that

$[\mathrm{t}]$ he institution called property guards the troubled boundary between individual man and the state ... Property draws a circle around the activities of each private individual or organization. Within that circle, the owner has a greater degree of freedom than without. Outside, [they] must justify or explain [their] actions, and show [their] authority. Within, [they are] master, and the state must explain and justify any interference ... Thus, property performs the function of maintaining independence, dignity and pluralism in society by creating zones within which the majority has to yield to the owner. ${ }^{24}$

Later, Reich stressed that the individual should possess, and property should provide, 'a small but sovereign island of [one's] own'. ${ }^{25}$ This idea that property is an island is a key feature of classical liberal thought. Within the shores of your island you can do what you wish, no matter how unwise or counterproductive (providing you do not hurt anyone else). ${ }^{26}$ The consequences of this approach to ownership for the environment and for collective actions problems (like climate change) have been identified by many. ${ }^{27}$

On a practical level, the classical liberal conception of private property is often articulated as consisting of a 'bundle' of legal rights or relations. ${ }^{28}$ At a minimum, this bundle must consist of what is coined the 'liberal triad' of possession, use, and disposition. ${ }^{29}$ As Waldron notes:

No one in the modern debate about property needs to be told that, from a legal point of view, ownership is not a single right but comprises a bundle of rights, of various Hohfeldian shapes and various sizes. An owner of land characteristically has the privilege of using the land, the right that others not come on it or use it without his permission, the power to alienate it completely through gift or sale, or in part, or for a period by leasing it, the liability to have it seized by creditors in the event of unpaid debt or bankruptcy, and so on. ${ }^{30}$

23 Sheila R Foster and Daniel Bonilla, 'The Social Function of Property: A Comparative Perspective' (2011) 80(3) Fordham Law Review 1003, 1003, 1008.

24 Charles Reich, 'The New Property' (1964) 73(5) Yale Law Journal 733, 733, 771.

25 Margaret Jane Radin, Reinterpreting Property (University of Chicago Press, 1993) 130, citing ibid 774.

26 Ibid. To date, no one appears to have successfully argued that climate change comes within the proviso; partly because tort law usually involves a claim that ' $A$ ' has been harmed by ' $B$ ' and it may be very difficult to establish that an individual carbon emitter's behaviour has harmed a multitude (or even an individual) 'A'. However, it may only be a matter of time before such an argument is successful: see Douglas A Kysar, 'What Climate Change Can Do about Tort Law' (2011) 41(1) Environmental Law 1.

27 See, eg, Aldo Leopold, A Sand County Almanac: And Sketches Here and There (Oxford University Press, 1949) vii-viii, 167-8; David Grinlinton and Prue Taylor (eds), Property Rights and Sustainability: The Evolution of Property Rights to Meet Ecological Challenges (Martinus Nijhoff, 2011).

28 Space does not allow for a full treatment of the 'bundle of rights' idea of property. This is an almost ubiquitous view of property, within which the 'bundle' can be seen as a collection of legal rights or relations regarding the control of goods and resources. Each legal right or relation is one 'stick' of a bundle that, taken as a whole, constitutes property. The classic exposition of the bundle of rights metaphor is found in Honoré's 1960s essay 'Ownership': AM Honoré, 'Ownership' in AG Guest (ed), Oxford Essays in Jurisprudence (Oxford University Press, 1961) 107. However, this idea is not without its critics: see, eg, Daniel B Klein and John Robinson, 'Property: A Bundle of Rights? Prologue to the Property Symposium' (2011) 8(3) Economic Journal Watch 193; Henry E Smith, 'Property is Not Just a Bundle of Rights' (2011) 8(3) Economic Journal Watch 279.

29 Babie, 'Idea, Sovereignty, Eco-Colonialism and the Future' (n 21 ) 532.

30 Jeremy Waldron, The Rule of Law and the Measure of Property (Cambridge University Press, 2012) 66 (citations omitted). 
In summary, under Western classical liberal property law, owners of estates and interests in land are entitled to exercise a 'triad' of rights, being possession, use, and alienation, in their own self-interest, and as a privilege arising from the input of labour or capital. ${ }^{31}$ According to Babie, this is a "shorthand way of saying that individuals enjoy choice ... about the control and use of goods and resources in accordance with, and to give meaning to, a chosen life project' ${ }^{32}$

\section{B Counter-Traditions within Western Accounts of Ownership}

Although the classical liberal tradition has certainly achieved dominance in political and cultural discourse over the last 300 years, much recent property law scholarship has been devoted to exploring the somewhat obscured countertraditions within it. ${ }^{33}$ These counter-traditions can trace their roots far further back than classical liberalism, and all of which suggest that there has never been a period where the interests of the individual were always prioritised above the needs of the community. Indeed, this scholarship also suggests these ideas of property are alive, if not well recognised, in how property law operates today. ${ }^{34}$

Essentially, the various different articulations of this counter-tradition make it clear that private property is a social institution aimed at serving an essentially social function. The purpose of private property is not solely to provide for individual autonomy, rather, autonomy arises as a consequence of the social nature of humans and the communities in which they chose to live. ${ }^{35}$ As a consequence, the ability of individuals to use their property solely as they wish will always be subject to the overarching needs of the community. ${ }^{36}$ For example, on the account of this tradition developed by Alexander, the overarching normative goal of our private property regimes is to enable the individual to flourish. ${ }^{37}$ Importantly, because humans are social creatures whose individual autonomy, and ability to flourish, is enabled by the communities in which they live, private property rights are inherently relational. Sometimes owners of property will owe obligations to

31 Margaret Jane Radin, 'The Liberal Conception of Property: Cross Currents in the Jurisprudence of Takings' (1988) 88(8) Columbia Law Review 1667-8. See also France-Hudson, 'Surprisingly Social' (n 7) 117.

32 Babie, 'Idea, Sovereignty, Eco-Colonialism and the Future' (n 21) 532.

33 See France-Hudson, 'Surprisingly Social' (n 7) 106-7; Gregory S Alexander, Property and Human Flourishing (Oxford University Press, 2018) xi-xii; Gregory S Alexander, 'Ownership and Obligations: The Human Flourishing Theory of Property' (2013) 43(2) Hong Kong Law Journal 451, 461-2; Grinlinton and Taylor (n 27); Gregory S Alexander, 'The Complex Core of Property' (2009) 94(4) Cornell Law Review 1063; Gregory S Alexander, 'Pluralism and Property' (2011) 80(3) Fordham Law Review 1017; Foster and Bonilla (n 23); Colin Crawford, 'The Social Function of Property and the Human Capacity to Flourish' (2011) 80(3) Fordham Law Review 1089; Rose, Property and Persuasion: Essays on the History, Theory, and Rhetoric of Ownership (n 2); Gregory S Alexander, Commodity and Propriety: Competing Visions of Property in American Legal Thought 1776-1970 (University of Chicago Press, 1997).

34 France-Hudson, 'Surprisingly Social' (n 7) 110.

35 Alexander, 'The Complex Core of Property' (n 33); Alexander, 'Pluralism and Property' (n 33); Foster and Bonilla (n 23); Crawford (n 33).

36 See generally Gregory S Alexander and Eduardo M Peñalver (eds), Property and Community (Oxford University Press, 2010).

37 See, eg, Alexander, Property and Human Flourishing (n 33). 
others and this fact tempers an owner's ability to use their property solely as they wish, and 'the collective community interest may take priority over the private interests of the individual' ${ }^{38}$ Unlike the classical liberal focus on individual selfinterest, this view of property emphasises the relationship between people and the impact that the exercise of ownership rights can have on others.

Critically, the obligations that accompany property ownership are not imposed from external sources, but arise by the fact of ownership itself. Where an obligation, restriction, or limitation is imposed on how property can be used, this is not necessarily an illegitimate interference with the individual's property. Instead, it reflects the contours of the owner's property right. Whether such inherent obligation is brought to an owner's attention by being reflected in statute, common law, government policy or another external source, this does not change the fundamental fact that the restriction on how an owner uses their property is an inherent aspect of that ownership, or that the obligations are owed by the owner to the broader community. ${ }^{39}$ For example, as noted by Babie:

Regulation is law's means of mediating the relationships established by private property. In order to prevent the tyranny of the individual over the community, the underlying social functions and relationships of private property require monitoring and regulation of choice by corresponding moral imperatives, duties, and obligations. Over time, regulation preserves the social function of a private property right, whatever it might be, within a context of relatedness, thus limiting potentially harmful outcomes for others. Choice, then, because of the community formed through relationships, is not entirely unlimited and unfettered. Rather, because it operates within a network of social relationships that form a community, every system of private property is inherently limited by moral imperatives, duties, and obligations, imposed and enforced by law, so as not only to allow the holder of private property to choose personal preferences, but also to allow the state to prevent outcomes inimical to the legitimate interests of others. ${ }^{40}$

This far more compelling counter-tradition of private property has a number of ramifications for land ownership in the context of climate change, where the owners may have to assume obligations in order for the community as a whole to avoid the worst consequences of global warming. These alternative accounts, already existing within the Western tradition, provide lawyers, policy makers, and individuals with a principled account of how private property actually operates. Although its boundaries are still contested, its great strength is that it suggests that it is perfectly possible to structure land ownership regimes to impose both rights and obligations, in order to achieve a range of predictable ends. It follows that the institution of private property and the concept of ownership are flexible enough for activities relating to the use, possession, and alienation of land to contribute towards the mitigation of climate change.

What is perhaps the most interesting aspect of these accounts of one, or possibly more, counter-traditions is that they are not some sort of historical curiosity, but appear to exist in the way land ownership and property law operates

38 Ben France-Hudson, 'No Private Property Rights in the Atmosphere' in Paul Martin et al (eds), The Search for Environmental Justice (Edward Elgar, 2015) 105, 116.

39 Alexander, 'Ownership and Obligations: The Human Flourishing Theory of Property' (n 33 ) 453.

40 Paul Babie, 'Three Tales of Property, or One?' (2016) 25(4) Griffith Law Review 600, 606 (emphasis altered) (citations omitted). 
today. ${ }^{41}$ Responses to environmental problems, including climate change, are (perhaps paradoxically) one area of the law in which these concepts of ownership are most evident. ${ }^{42}$ This is certainly true in Australia where the Carbon Credits $A c t$, for example, reflects the social obligations inherent in the broader concept of ownership in two ways: first, as a mechanism that creates personal property in the form of carbon credits that enable Australia to contribute towards fulfilling its obligations at international law; and second, as a mechanism through which landowners can act upon the social obligations inherent to their land ownership, by choosing to undertake land-based activities that mitigate or offset GHG emissions. Social obligation accounts of property are of particular importance in the climate change context because they provide a principled basis on which to explain how the property created by the Carbon Credits Act actually works in practice; this will be particularly important when priority disputes arise between owners of various estates or interests in land. They also illustrate why property may be a powerful tool in combating climate change, notwithstanding the fact that the institution of property has itself contributed to the challenges that are now attempting to be resolved within its boundaries. ${ }^{43}$

\section{Australia's Commitments under International Law}

By deciding to implement mitigation projects under the Carbon Credits Act, landowners, or proponents of mitigation activities with owners' consent, commit the project land to the environmental objectives of the Carbon Credits Act. This includes an objective to mitigate or avoid GHG emissions, in order to meet Australia's commitments under international climate change treaties. ${ }^{44}$ As such, international climate change treaties - including the United Nations' Framework Convention on Climate Change, ${ }^{45}$ the Kyoto Protocol, ${ }^{46}$ and the Paris Agreement ${ }^{47}$ - give context to domestic action taken in Australia to mitigate GHG emissions and adapt to climate change. Australia has a dualist system of translating international law into its domestic sphere; ${ }^{48}$ which means while Australia is a state party to each of these international treaties, a separate act must be enacted to bind Australia to its specific obligations thereunder at a national level. While the Carbon Credits Act does not perform this function, the first of its stated objectives is to remove and avoid the emission of GHG emissions from the atmosphere in order to meet Australia's obligations under the United Nations' Framework Convention on Climate Change, Kyoto Protocol, and any succeeding treaty (ie, the

\footnotetext{
41 France-Hudson, 'Surprisingly Social' (n 7) 112.

42 France-Hudson, 'No Private Property Rights in the Atmosphere' (n 38) 105.

43 Paul Babie, 'Private Property: The Solution or the Source of the Problem?' (2010) 2(2) Amsterdam Law

Forum 17, 22.

44 Carbon Credits Act s 3(2).

45 Framework Convention on Climate Change, opened for signature 14 June 1992, 1771 UNTS 107 (entered into force 21 March 1994).

46 Kyoto Protocol to the Framework Convention on Climate Change, opened for signature 15 March 1999, 2303 UNTS 162 (entered into force 16 February 2005).

47 Paris Agreement, UN Doc FCCC/CP/2015/L.9/Rev.1 (n 10).

48 Commonwealth v Tasmania (1983) 158 CLR 1, 129-32 (Mason J).
} 
Paris Agreement). ${ }^{49}$ As such, the text of these treaties provide context for the statutory scheme established by the Carbon Credits Act, and may be referred to in applying or interpreting its provisions..$^{50}$ Notably, the Carbon Credits Act, and the GHG emissions mitigation projects that it encourages private citizens to undertake, contribute to a 'bottom-up' or 'grassroots' approach ${ }^{51}$ to mitigating GHG emissions and adapting to climate change, which underpins the most recent Paris Agreement. A decision to voluntarily implement ERF projects on private land under the Carbon Credits Act by landowners is one way that they may contribute towards mitigating GHG emissions while acting upon the social obligations inherent in their ownership of land; doing the 'right thing' with what one owns is as much evidence of social obligation as such behaviour being imposed by an external source ${ }^{52}$ (even where doing the right thing is accompanied by a profit (indeed not doing the right thing may be much more profitable)).

\section{Obligations Owed by Individual Landowners}

In terms of increasing carbon abatement, the Carbon Credits Act intends this to occur in a manner that (i) is consistent with the protection of Australia's natural environment, and (ii) improves resilience to the effects of climate change. ${ }^{53}$ These objectives clearly reflect the increased modern awareness of the interconnectedness of all environmental systems and the need for individuals to temper how they use their land in order to safeguard those systems. Although still contested, a consensus is building that environmental laws are completely separate from the regulatory framework that applies to real property. The application of environmental laws to real property is not an example of illegitimate interference by the state into some sort of sacrosanct area of complete individual autonomy. Rather, as Babie notes:

The choices people make as to how to use land are the cause of climate change and so it is those very choices, made possible by the concept of private property and the things we control through its implementation, that $d o$ need to be constrained if we are to respond to climate change. That constraint, in the form of planning law, is property law. ${ }^{54}$

The obligations imposed by the Carbon Credits Act reflect this observation. Climate change causes changes to land $^{55}$ and is leading to changes in the management of natural environments. ${ }^{56}$ These changes are encouraged and

49 Carbon Credits Act s 3.

50 Acts Interpretation Act 1901 (Cth) ss $15 \mathrm{AA}-15 \mathrm{AB}$.

51 See, eg, Robert Falkner, 'The Paris Agreement and the New Logic of International Climate Change Politics' (2016) 92(5) International Affairs 1107.

52 For example, the work of Ostrom points to many examples where a self-regulating property regime is accompanied by strong societal expectations about the way in which the property held by individuals is used: see Elinor Ostrom, Governing the Commons: The Evolution of Institutions for Collective Action (Cambridge University Press, 1990); Elinor Ostrom et al (eds), The Drama of the Commons (National Academies Press, 2002).

53 Carbon Credits Act s 3.

54 Babie, 'Three Tales of Property, or One?' (n 40) 613 (emphasis in original).

55 See above $\mathrm{n} 9$.

56 Governments and public authorities at all levels are considering how to manage risks associated with climate change in coastal zones and areas subject to bushfire and drought: see, eg, House of 
supported by laws that engage with, and utilise, the interests of owners, which are consistent with notions of private property because they are entered into voluntarily by landowners for profit. At the same time, however, payments received by landowners for implementing ERF projects on private land may not provide adequate compensation (for them or their successors in title) for the restrictions consequentially imposed on their rights by the Carbon Credits Act. While challenging land ownership in this way is not the primary objective of the Carbon Credits Act, the relationship that the Carbon Credits Act has with land in Australia is great, due to the proportion of land-based projects implemented under it.

Moreover, the Carbon Credits Act is not the only law that contributes towards Australia's response to climate change that affects land directly. These other laws also reflect the fact that sometimes land ownership is a two-way street and that owners can have obligations relating to their land that are dictated by the common interest. For example, both state forestry and environmental protection and biodiversity laws reflect the fact that individuals cannot use their land in a completely free manner. While these regimes can encompass environmental imperatives beyond climate change, each of them is also relevant to attempts to address climate change challenges. For example, forestry schemes exist in all Australian states, as a legacy of measures taken to reduce land clearing by promoting investment in forests. 57 In Victoria, forestry projects involving carbon sequestration are administered under the state climate change law,58 and so reflects a similar conception of land ownership as that found in the national Carbon Credits Act.59 This reinforces the idea that landowners do have a role in efforts to mitigate climate change arising from a social obligation that is inherent to their ownership. In other states, forestry schemes, administered as part of real property or by stand-alone forestry laws, 60 contain provisions that impose requirements on scheme owners to manage and care for land during the project term. These also reflect burdens on ownership that fetter the use of land by individual owners.

Representatives Standing Committee on Climate Change, Water, Environment and the Arts, Parliament of Australia, Managing Our Coastal Zone in a Changing Climate: The Time to Act Is Now (Report, October 2009); Nicole Gurran et al, Planning for Climate Change Adaptation in Coastal Australia: State of Practice (Report No 4 for the National Seachange Taskforce, Faculty of Architecture, Design and Planning, University of Sydney, November 2011); Hamish Clarke, 'Climate Change Impacts on Bushfire Risk in NSW' (Technical Brief, Office of Environment \& Heritage (NSW), November 2015); Climate Council, Deluge and Drought: Australia's Water Security in a Changing Climate (Report, 2018).

57 Pamela O'Connor et al, 'From Rights to Responsibilities: Reconceptualising Carbon Sequestration Rights in Australia' (2013) 30(5) Environmental and Planning Law Journal 403, 404; Pamela O'Connor, 'The Extension of Land Registration Principles to New Property Rights in Environmental Goods' in Martin Dixon (ed), Modern Studies in Property Law (2009) vol 5 363, 376-7. See also Department of Agriculture and Water Resources (Cth) 'Growing a Better Australia: A Billion Trees for Jobs and Growth' (Report, 2018).

58 Climate Change Act 2017 (Vic).

59 For example, they provide for agreements regarding the management of private land use for sequestration projects to be entered into between landowners and the state: see ibid $\mathrm{s} 1$.

60 Conveyancing Act 1919 (NSW) s 88EA; Forestry Act 1959 (Qld); Forest Property Act 2000 (SA); Forestry Rights Registration Act 1990 (Tas); Carbon Rights Act 2003 (WA). 
Although not directly related to GHG mitigation, 'conservation covenants' continue this trend in Australian real property law. Conservation covenants may be entered into voluntarily by landowners to protect natural resources and biodiversity on private land indefinitely, or can be imposed by the state in relation to an application to implement a forestry project. ${ }^{61}$ According to a recent study, more than 7,000 conservation covenants exist on private land across Australia ${ }^{62}$ While these laws therefore comprehensively reflect social obligations relating to the protection and conservation of land for communal benefit, they can also been seen as making a tangible contribution to Australia's response to climate change, by restricting land use and improving the resiliency of the natural environment to changing conditions, being a stated objective of the Carbon Credits Act. ${ }^{63}$

Social obligations, sometimes extending to a responsibility to care and tend to land, are expressly and implicitly reflected in a range of different pieces of legislation, including those with specific objectives and provisions addressing general environmental protection, biodiversity conservation and land management, as well as issues specifically relevant to the mitigation of climate change. Many of these laws have existed for a long time, suggesting that the social obligations inherent in ownership are nothing new. Laws tempering the rights exercised by landowners, in the public interest, are legion. They range from general restrictions of use, for example under long-standing torts of nuisance and negligence, to laws of 'takings' in the context of planning law, where Viscount Simonds notes that 'it is clear that such a diminution of rights can be affected without a cry being raised that Magna Carta is dethroned or a sacred principle of liberty infringed' ${ }^{64}$ Even with regard to Crown acquisition of land, perhaps the most coercive property-focused step the state can take, there are no absolute rights. As recently noted by French CJ in the context of compulsory acquisition of land, although property is afforded a range of protections, these have never been absolute:

Private property rights, although subject to compulsory acquisition by statute, have long been hedged about by the common law with protections. These protections are not absolute but take the form of interpretive approaches where statutes are said to affect such rights. ... The attribution by Blackstone, of caution to the legislature in exercising its power over private property, is reflected in what has been called a presumption, in the interpretation of statutes, against an intention to interfere with vested property rights ...65

Qualification of rights arising from land ownership on environmental grounds have appeared more recently, as individual fishing quota regimes, or water rights schemes, have been established in Australia and around the world. ${ }^{66}$ In New

61 EDO Tasmania, Conservation Covenants: Options to Improve Security for the Protection of Private Land in Tasmania (Report, May 2017) 5; Department of Environment, Climate Change and Water (NSW), 'Conservation Partnerships: A Guide for Landholders' (Handbook, 2010) 4. Matthew Hardy et al, 'Exploring the Permanence of Conservation Covenants' (2017) 10(2) Conservation Letters 221, 222.

63 Carbon Credits Act s 3.

64 Belfast Corporation v OD Cars Ltd [1960] AC 490, 519 (Viscount Simonds).

$65 \quad R \&$ R Fazzolari Pty Ltd v Parramatta City Council (2009) 237 CLR 603, 618-9 [40] (French CJ) (emphasis added).

66 For example as discussed by O'Connor (n 57) 367-70. 
Zealand, for example, the Court of Appeal has noted in the context of fishing quota (aimed at preserving fishing stocks at a level of maximum sustainable yield) that

[w]hile acknowledging the extensive arguments which we heard on the property rights point, we consider the answer is quite straight forward. While quota are undoubtedly a species of property and a valuable one at that, the rights inherent in that property are not absolute. They are subject to the provisions of the legislation establishing them. That legislation contains the capacity for quota to be reduced. If such reduction is otherwise lawfully made, the fact that quota are a 'property right' ... cannot save them from reduction. That would be to deny an incident integral to the property concerned. There is no doctrine of which we are aware which says you can have the benefit of the advantages inherent in a species of property but do not have to accept the disadvantages similarly inherent. ${ }^{7}$

However, with the proliferation of schemes to address the world's manifold environmental problems, the reality that the dominant conception of ownership does not tell the whole story is becoming increasingly apparent. Carbon sequestration schemes in the Carbon Credits Act, and in state-based forestry schemes, are simply recent illustrations of this. It is no surprise that climate change is helping to clarify the true nature of what it means to own land in a carbonconstrained environment. It is an archetypal example of a collective action problem at large. Arguably, however, the institution of private property is a fundamental part of the problem in the first instance. ${ }^{68}$ Nonetheless, many responses to climate change, including the tools adopted by Australia under the Carbon Credits Act, are attempts to harness individual self-interest and the concept of ownership as it applies to land in order to achieve positive environmental outcomes. ${ }^{69}$ If the rights inherent in the dominant idea of land ownership were to operate in the sense anticipated by classical liberal thought it is likely that the desired outcome would not be achieved. In this regard, specific climate change laws are not only evidence of the expanding circumstances in which social obligations are being recognised in relation to ownership of land, but provide further evidence that our understanding of ownership of land has never truly been settled, but is continually evolving.

\section{THE IMPACT OF SOCIAL OBLIGATIONS ON LAND TITLE AND OWNERSHIP IN THE CONTEXT OF CLIMATE CHANGE}

The fact Australia has accepted that it has international obligations to respond to climate change, and has adopted legislation to fulfil those obligations, however, is not the only evidence of counter-traditions of private property and ideas of ownership at work in Australian law. The particular rules affecting ownership of land imposed by these legislative schemes provide further support for the argument that the dominant Western liberal conception of ownership lacks predictive truth. Moreover, the major problems from which these regimes suffer stem, at least in 
part, from the fact that policy makers and legislative drafters have not clearly articulated the rights and obligations that accompany these new tools, nor have they carefully thought through the consequences of these schemes on land ownership. ${ }^{70}$

Australia achieves its climate change objectives by laws and regulations that encourage and discourage a range of activities, including those which relate directly to land. While participation in these schemes by landowners is voluntary, the impact that these activities can have on landowners, particularly the current owner's successors in title, are not. Laws that apply to land-based activities engage with land ownership in different ways, permitting or prohibiting owners from exercising some or all of the liberal 'triad' of possession, use, and alienation, that would normally be associated with owning different estates and interests in land. Problems arise not only when climate change laws do not fully consider the potential impact that their mechanisms may have on land ownership, and so must be accommodated within existing real property regimes, which may themselves need to be contemporaneously adapted to accommodate changing social and environmental standards.

This Part explores how the Carbon Credits Act relates to the Torrens System of land title by registration, and the mechanisms through which inherent social obligations of ownership are enforced. By way of comparison, it also considers state forestry laws in respect of carbon sequestration rights, and laws for environmental protection and biodiversity conservation in respect of conservation covenants. In contrast to the Carbon Credits Act, while still reflecting an idea of property containing inherent obligations, these laws typically do a much better job of integrating a new environmental management tool with existing real property laws.

\section{A The Carbon Credits Act and Its Application to Land-Based Activities}

Ownership of land is affected by climate change laws where a project to mitigate GHG emissions is implemented on land under the Carbon Credits Act, supported by funding from the ERF. Establishment of such an ERF project requires successful completion of a complex two-stage process set out in the Carbon Credits Act. In the first stage, an entity with the legal right to carry out an 'eligible offsets project', known as a 'project proponent' ('proponent'), ${ }^{71}$ applies to the governing Clean Energy Regulator ('Regulator') for carbon credits, each of which represents one tonne of carbon dioxide or carbon-dioxide-equivalent GHG. ${ }^{72}$ The proposed project must meet specific prescribed eligibility criteria, ${ }^{73}$ which include

70 Ben France-Hudson, ‘Statutory Property: Is It a Thing?’ (2016) 47(3) Victoria University of Wellington Law Review 411, 422; Samantha Hepburn, 'Carbon Rights as New Property: The Benefits of Statutory Verification' (2009) 31(2) Sydney Law Review 239.

71 Carbon Credits Act s 5.

72 'Australian Carbon Credit Units', Clean Energy Regulator (Web Page, 15 December 2017) $<\mathrm{http}: / /$ www.cleanenergyregulator.gov.au/OSR/ANREU/types-of-emissions-units/australian-carboncredit-units>; Carbon Credits Act ss 11(1), 18(2).

73 Carbon Credits Act s 27. Eligibility criteria cover a wide variety of issues, and discussion of them is outside the scope of this paper. For discussion of some criteria which affect land-type projects: see 
being designed according to a methodology determination ${ }^{74}$ that sets out the conditions and requirements for projects involving particular activities. If the proponent and its project satisfy these requirements, the Regulator will issue carbon credits to that project, which are personal property of the proponent..$^{75}$ It is useful to provide an example of how this might work, as this will help to provide concrete illustrations of some of the problems with the scheme and its impact on ownership. ${ }^{76}$ Proponent A decides to revegetate approximately 180 hectares of its Victorian property with native trees. This will not only provide for carbon sequestration, but will also impact positively on shelter for livestock, increase the quality of pasture, improve amenity and aesthetics of the land, and contribute to biodiversity conservation. Proponent A designs the project in accordance with the Carbon Credits (Carbon Farming Initiative) (Reforestation by Environmental or Mallee Plantings) Methodology Determination 2014 (Cth) ('Methodology Determination'), which includes, for example, that the land has been clear of tree cover for at least five years. ${ }^{77}$ Under the Methodology Determination, carbon sequestered in native trees is calculated to provide GHG offsets of 3,300 tonnes. As the fee simple owner of the land, Proponent A applies to the Regulator for a declaration that the revegetation is an 'eligible offsets project' under the Carbon Credits Act. Having met the prescribed conditions, the Regulator makes the declaration and issues 3,300 carbon credits to Proponent A.

In the second stage, a proponent may participate in a reverse auction to sell its carbon credits to the Australian government. ${ }^{78}$ Reverse auctions are designed to encourage 'least cost' mitigation of GHG emissions across all economic sectors. ${ }^{79}$ Since 2014, eight reverse auctions have been carried out, resulting in the sale of 193 million carbon credits by proponents at an average price of $\$ 12$ each. ${ }^{80}$ At this

Vanessa Johnston, 'Sowing the Seed of Change: Why Australia's Land Sector Needs a Carbon Price to Encourage Mitigation of GHG Emissions and Promote Sustainable Land Use' in Natalie P Stoianoff et al (eds), Market Instruments and the Protection of Natural Resources (Edward Elgar, 2016) 35, 37-8. See generally 'Eligible Activities', Department of the Environment and Energy (Web Page)

$<\mathrm{http}$ ://www.environment.gov.au/climate-change/emissions-reduction-fund/methods $>$.

77 Carbon Credits (Carbon Farming Initiative) (Reforestation by Environmental or Mallee Plantings) Methodology Determination 2014 (Cth) r 2.3 ('Methodology Determination').

78 Carbon Credits Act s 20F. The eighth ERF auction was held on 10-11 December 2018: see 'Auction December 2018' Clean Energy Regulator (Web Page, 5 March 2019)

$<$ http://www.cleanenergyregulator.gov.au/ERF/Auctions-results/december-2018>.

79 Carbon Credits Act s 20G.

80 Ibid s 20F; 'Auction December 2018', Clean Energy Regulator (Web Page, 5 March 2019)

$<\mathrm{http}$ //www.cleanenergyregulator.gov.au/ERF/Auctions-results/december-2018>. 
price, the most commercially viable land-based projects include those which avoid land clearing or deforestation, or the revegetation of agricultural or previously cleared land as it can be completed at a 'modest' cost,${ }^{81}$ compared to revegetation of (for example) semi-arid land, or tropical rainforest. ${ }^{82}$ Returning to the hypothetical example, while Proponent A's costs for seed or seedlings (tube stock) is likely to be low, ${ }^{83}$ labour costs, tree guards, fencing, pruning, watering, and monitoring costs also need to be taken into account. If Proponent A sold 3,300 carbon credits to the Australian government for $\$ 12$ each, this would equate to $\$ 39,600$. While this may cover costs associated with planting seeds or seedlings, it may not cover ongoing costs to maintain fences and water infrastructure. ${ }^{84}$ Moreover, ERF funding is unlikely to provide adequate compensation to landowners for the restrictions consequently imposed on their ownership by the Carbon Credits Act.

A project proponent that succeeds in selling its carbon credits at the reverse auction will enter into a contract with the Regulator as an agent for the Australian government (a 'carbon contract'), ${ }^{85}$ to deliver the project over a term of up to 25 years. ${ }^{86}$ Importantly, projects involving carbon sequestration in vegetation or soil must guarantee sequestration for a defined 'permanence period' of either 25 or 100 years. ${ }^{87}$ If a proponent selects the shorter permanence period, the proponent will receive $20 \%$ fewer carbon credits at the completion of their project. ${ }^{8}$ Perhaps this is the reason that many carbon sequestration projects registered under the Carbon Credits Act have longer permanence periods of 100 years; 295 of the 519 projects (57\%) currently identified in the ERF Register adopt the longer permanence period of 100 years..$^{89}$ Essentially, the decision made by a proponent to implement a carbon sequestration project under the Carbon Credits Act 'locks in' the project land use for 100 years, which is at least 75 years longer than the term of any carbon contract. Until this point, it is worthwhile reiterating that the process undertaken by a proponent, such as Proponent A, is voluntary; there is no law that yet requires specific landowners implement projects on specific land to reduce or avoid GHG emissions by means that directly affect that land. The proponent can also choose

81 See Brett A Bryan et al, 'Land Use Efficiency: Anticipating Future Demand for Land-Sector Greenhouse Gas Emissions Abatement and Managing Trade-Offs with Agriculture, Water, and Biodiversity' (2015) 21(11) Global Change Biology 4098.

82 Jacki Schirmer and John Field, The Cost of Revegetation (Final Report, January 2000) 78, 82, 85, 88; Carla P Catterall and Debra A Harrison, Rainforest Restoration Activities in Australia's Tropics and Subtropics (Research Report, June 2006) 35-6, 38-40.

83 See, eg, Schirmer and Field (n 82) 49. Seedlings planted by Williams were reported to cost between \$4-6 each depending on fencing requirements: Williams, 'Cost-Effective Landscape Revegetation' (n 76) 467. For example, total costs of revegetating agricultural land has been reported as $\$ 2,000$ per hectare: compare Williams, 'Cost-Effective Landscape Revegetation' (n 76) 466 with Schirmer and Field (n 82) 85.

85 Carbon Credits Act s 20B. A carbon contract consists of a code of 'common terms' (the current version 3 is published on the Clean Energy Regulator's website), and a separate schedule of commercial terms which are confidential as between the parties.

86 Carbon Credits Act ss 69(2), (3).

87 Ibid s 27(3).

88 Ibid ss 16(2), 86A.

89 'Emissions Reduction Fund Project Register', Clean Energy Regulator (Web Page, 28 June 2019) $<$ http://www.cleanenergyregulator.gov.au/ERF/project-and-contracts-registers/project-register>. 
the length of the permanence period attached to their mitigation or offsets project. However, while these decisions (and their consequences) are voluntary for the proponent, and any owner of an estate or interest in that land who has given consent to establish the ERF project, this is not the case for their successors in title unless they purchase their interest in the relevant land expressly subject to those restrictions.

The permanence period associated with ERF projects has a crucial impact on ownership. One immediate implication becomes clear after considering the not unlikely risk that carbon sequestered by these projects might be reversed during the contract term or longer permanence period. Reversal can occur if vegetation is destroyed or damaged by natural disturbances such as bushfire, flood, drought, pests, or disease. ${ }^{90}$ Ironically, climate change only increases the likelihood of events such as these occurring in Australia. Alternatively, destruction or damage can be caused by human acts, for example: felling, harvesting, or cutting vegetation; disease caused by the release of pollutants or pests; poisoning; or other intentional damage. In any case carbon previously sequestered in vegetation is released back into the atmosphere. Reversal affecting more than $5 \%$ of the project area is deemed 'significant', ${ }^{91}$ and if carbon sequestration is not restored to the former 'benchmark' level by the proponent, ${ }^{92}$ will result in a demand for the relinquishment of carbon credits. ${ }^{93}$ If carbon credits are not relinquished, then the Regulator will impose a carbon maintenance obligation ('CMO') on the project (and project land) ${ }^{94}$ Returning to our hypothetical example: assume that Proponent A started its revegetation project in 2015; while the project (and its contract with the Regulator) will terminate in 2040, it has elected a permanence period of 100 years in order to receive the full number of carbon credits generated by the project. Accordingly, Proponent A has statutory obligations to maintain sequestration at benchmark levels set for the project until 2115. During the project term, Proponent A maintains the vegetation and manages the land (ie, restricts grazing and harvesting, and acts to minimise the risk of natural and unnatural disturbance) as required by the Methodology Determination. Proponent A receives final payment for its carbon credits in 2040 when the project and contract term ends. In 2060, however, a severe bushfire damages or destroys all of the trees. Despite the project being complete, the Regulator issues a relinquishment request to Proponent $\mathrm{A}$ for the carbon credits issued to the project when Proponent A fails to restore sequestration to benchmark levels. Proponent A also fails to relinquish the carbon credits, and so the Regulator imposes a CMO on the project and the project land.

Importantly, the obligation to fulfil a CMO falls on 'the owner or occupier' of the project land, ${ }^{95}$ whoever that might be, at that time. Thus, in our example it may be the original proponent, Proponent A. However, it is also possible that the obligation to fulfil a CMO could fall on entities who are not, and never have been,

\footnotetext{
90 Carbon Credits Act ss 90-1.

91 Carbon Credits (Carbon Farming Initiative) Rule 2015 (Cth) rr 81-2.

92 Carbon Credits Act ss 97(2A), (4), (9), (10).

93 Ibid s 97(1)(b), or is unlikely to comply as determined by the Regulator.

94 Ibid ss 90, 91, 97(14).

95 Ibid s 97(10) (emphasis added).
} 
a party to the ERF transaction, ${ }^{96}$ due to the length of the permanence period for ERF projects. While the project proponent and current owner may have privity of contract regarding the sale of land as vendor and purchaser, this contract may not have addressed the existence of former ERF project, or provided for the event of a CMO. Once the transfer of land is complete, the current owner (purchaser) may have no recourse against the former owner (vendor).

Moreover, while the Regulator maintains a public 'ERF Register' containing key information about ERF projects such as relinquishment requirements and CMOs as 'a point of reference for people wanting to buy land that has a sequestration offsets project on it so they can factor into the sale price the potential costs and benefits of the project', ${ }^{97}$ the ERF Register is separate to the central land Register maintained under the Torrens system. In the context of climate change, land ownership is also impacted by the ineffective connection made between the Carbon Credits Act and the Torrens system, which is explored next.

\section{B Mechanisms Affecting the Register: Carbon Sequestration and Conservation Interests in Land}

Beyond tying up the use of land during a permanence period of up to 100 years, the Carbon Credits Act challenges traditional ideas of land ownership because while it includes a mechanism that gives the Torrens Registrar of Titles ('Registrar') discretion to make entries or notations relating to ERF projects on the central Torrens Land Register ('Register'), it does not clearly identify the nature of estates or interests that support such entries. These entries or notations are a poor fit with existing processes that provide for the safe and efficient transfer of estates and interests in land.

It is particularly problematic that this mechanism does not clearly draw the connection between the rights and obligations created under the Carbon Credits Act and its effect on title and ownership of land. This can be contrasted to the Torrens approach to notifying estates and interests in land, and the processes used in other environmental laws to record interests against land title. This is problematic, not least due to the discretionary power that is given by Carbon Credits Act sections 39-40 to land registry officials to make entries or notations on the land Register in order to draw attention either to the existence of the ERF project (section 39) or a CMO (section 40).

If such an entry is made on the Register it is likely to serve the purpose of providing notice of the rights and obligation imposed by the Carbon Credits Act. However, it is important to recognise that this was not a purpose that the Torrens system was designed to serve. Rather, the Register is intended to provide a complete and accurate reflection of all estates and interests in land..$^{98}$ Although the

\footnotetext{
96 See below Part III(D). The proponent may be a separate entity to the landowner; for example, carrying out the project on land under a lease or contractual licence, including by 'carbon offset providers' who deal in secondary markets for carbon credits.

97 'Emissions Reduction Fund Project Register' (n 89).

98 See, eg, R Stein, 'The "Principles, Aims and Hopes" of Title by Registration' (1983) 9(2) Adelaide Law Review 267.
} 
Torrens system can accommodate unregistered estates and interests in land, ${ }^{99}$ by express statutory notations and recordings, ${ }^{100}$ by caveat, ${ }^{101}$ priority notice, ${ }^{102}$ or as a statutory exception to indefeasibility, ${ }^{103}$ each of these mechanisms applies to limited classes of proprietary estates and interests in land. However, the rights and obligations imposed under the Carbon Credits Act do not fit within the recognised categories. ${ }^{104}$

The fact that the Carbon Credits Act is utilising the Torrens system in order to achieve its ends indicates a change in the way the obligations associated with land ownership are being broadcast, and suggests that our understanding of ownership is evolving. When people buy and sell this land the Carbon Credits Act suggests that all parties be made aware of the obligations that accompany ownership of that piece of land. This is novel, ${ }^{105}$ and there is no doubt that the mechanism created by Carbon Credits Act sections 39-40 is expressly intended to give notice of matters relating to emissions mitigation projects. This is reinforced not only in the explanatory paragraphs contained in ERF transaction documents, ${ }^{106}$ but also in materials published by the Regulator. ${ }^{107}$ Consequently, the Regulator regards the notification mechanism within the Carbon Credits Act as an essential tool to make entities aware of the existence of an ERF project when dealing with land. ${ }^{108}$

Despite this, entries or notifications made under the Carbon Credits Act are a poor fit with existing notification mechanisms in the Torrens system. For example, compared to caveats, Carbon Credits Act entries neither provide notice that an estate or interest is being claimed in land, ${ }^{109}$ nor do they prevent dealings with land title. Moreover, unlike priority notices, Carbon Credits Act entries are not 'placeholders' for expected registrable instruments. Nevertheless, Carbon Credits Act notifications do appear to uphold the fundamental purpose of notifying others about matters relating to land. For a system of land title by registration to 'suddenly

99 Barry v Heider (1914) 19 CLR 197. See further Les A McCrimmon, 'Protection of Equitable Interests under the Torrens System: Polishing the Mirror of Title' (1994) 20(2) Monash University Law Review 300 .

100 See, eg, Transfer of Land Act 1958 (Vic) s 88B(2).

101 See, eg, ibid s 89.

102 See, eg, ibid s 91C.

103 See, eg, ibid s 42(2).

104 See below Part III(C).

105 Hepburn (n 70) 251, 268.

106 'Eligible Interest Holder Consent' (Form No CER-ERF-EIH0001, Clean Energy Regulator, 23 June 2015) 12

$<$ http://www.cleanenergyregulator.gov.au/DocumentAssets/Documents/Eligible\%20interest\%20holder\% 20 consent $\% 20$ form.pdf $>$ states: 'Sequestration projects may be noted on land titles or relevant land registers to help to ensure that anyone buying property is aware if there is a sequestration project on it'.

107 'The registered proprietor of the land may be able to apply to their state and territory land registry to note their sequestration projects on the project land titles to ensure that anyone buying the property is aware of the project': 'The Emissions Reduction Fund and Permanence on Land' (Information Statement, Clean Energy Regulator) 2

$<$ http://www.cleanenergyregulator.gov.au/DocumentAssets/Documents/The\%20Emissions\%20Reduction $\% 20$ Fund $\% 20$ and $\% 20$ permanence $\% 20$ on $\% 20$ the $\% 201$ land.pdf $>$.

108 See generally ibid.

109 See, eg, Transfer of Land Act 1958 (Vic) s 89; Crampton v French [1995] V Conv R 54-529. The interest must be a separate and distinct interest in land: Swanston Mortgage Pty Ltd v Trepan Investments Pty Ltd [1994] 1 VR 672, 682 (Brooking J). 
and unexpectedly' saddle a person interested or entitled to deal with land with '[an] interest ... which could have been, but was not made the subject of ... a caveat' would be subversive. ${ }^{110}$ However, unlike the caveat system, the Carbon Credits Act neither allows a proponent to apply for entries or notifications to be made on the Register for their project, ${ }^{111}$ nor compels the Registrar to make any notifications or entries, ${ }^{112}$ which is the key database of information which would be searched by a person intending to deal with land. Returning to our hypothetical example, despite the Regulator imposing a relinquishment requirement on Proponent A, and subsequently a CMO on the project and project land due to Proponent A's failure to remedy the reversal of carbon sequestration arising from the bushfire within a reasonable time, the Regulator cannot compel the Registrar to make an entry on the Register against the relevant title regarding the existence of the CMO. The lack of any Register entry being made by the Registrar (and no power given to any other party to make it) means that an entity intending to deal with land in the future, perhaps 50 years, might be unaware of the obligation that awaits them despite searching the Register prior to purchasing an estate or interest in the land.

Furthermore, the notification system provided in the Carbon Credits Act is not supported by a corresponding provision of the Torrens system that reflects the proprietary nature of the interest in land. This could adversely affect the Registrar's willingness to exercise its discretion to make notations or entries regarding ERF projects and statutory obligations which may be imposed by the Act. On this basis, while the Carbon Credits Act reflects the existence of social obligations inherent to ownership, it does not provide any guidance about how they should be dealt with as a matter of ownership under property law. Indeed, it is not clear what sort of 'thing' is actually being noted on the title. In many respects, what is being noted on the Register reflects the statutory and contractual permanence obligations imposed on a proponent (who may or may not be the landowner) in relation to an ERF project, or the obligations attendant on a CMO. These are not common law or equitable proprietary interests; neither, as discussed in Part III(C), are they easily analogised to such recognised interests, or those created by statute. Perhaps the closest one could get is to say that the Carbon Credits Act is trying to create a positive covenant in gross, requiring the land to be used in a particular way. While this might be permitted in jurisdictions such as New Zealand, ${ }^{113}$ they do not yet fall within the existing classes of property which are currently recognised in Australia. ${ }^{114}$

110 Black v Garnock (2007) 230 CLR 438, 470 [80] (Callinan J).

111 The caveator must have reasonable cause regarding the claimed estate or interest in land: see Transfer of Land Act 1958 (Vic) s 118.

112 Compare ibid s 89 with Real Property Act 1900 (NSW) s 74G. Registration of caveats is not mandatory in all Australian states: see $J \&$ H Just (Holdings) Pty Ltd $v$ The Bank of New South Wales (1971) 125 CLR 546, 552 (Barwick CJ).

113 See Property Law Act 2007 (NZ) s 307A.

114 See, eg, Bernard Rudden, 'Economic Theory v Property Law: The Numerus Clausus Problem' in John Eekelaar and John Bell (eds), Oxford Essays in Jurisprudence: Third Series (Clarendon Press, 1987) 239, 239, 241; Ben McFarlane, 'The Numerus Clausus Principle and Covenants Relating to Land' in Susan Bright (ed), Modern Studies in Property Law (Hart Publishing, 2011) vol 6 311, 326; Brendan Edgeworth, 'The Numerus Clausus Principle in Contemporary Australian Property Law' (2006) 32(2) 
The approach under the Carbon Credits Act can be distinguished from the approach taken in state laws regarding forestry rights and conservation covenants, which each have a direct point of reference to the Torrens statutes. Under laws in six Australian states, a 'carbon sequestration right' (or similar) is either deemed to be a proprietary interest in land, ${ }^{115}$ or is verified as a novel property right, ${ }^{116}$ and can be registered as such under the Torrens statute of the relevant state. Commercial agreements that address issues incidental to carbon sequestration rights (eg, land access, land management, and tree maintenance) ${ }^{117}$ may also be registered in some states. ${ }^{118}$ In this respect, conservation covenants established voluntarily under state law between landowners and public authorities operate in a similar manner. ${ }^{119}$ Environmental protection and biodiversity conservation laws require the Registrar to record the legally binding agreements made between landowners and public authorities on the Register against the relevant land title. ${ }^{120}$ On this premise, forestry, and environmental protection and biodiversity conservation laws include mechanisms that enable rights and obligations associated with forestry or land conservation projects to be registered or recorded on the Register at the direction of the owner of those rights or obligations as deemed or verified proprietary interests in land. By their design, these laws recognise the importance of articulating how obligations affect ownership by deeming or verifying them as interests in land in their own right.

The absence of provisions in the Carbon Credits Act to deal with similar issues is a clear departure from the approach taken at state level which attempts to accommodate ownership. On its face, the mechanism for recording the existence

Monash University Law Review 387; Michael Weir, 'Pushing the Envelope of Proprietary Interests: The Nadir of the Numerus Clausus Principle?' (2015) 39(2) Melbourne University Law Review 651.

115 Conveyancing Act 1919 (NSW) s 88AB; Forestry Act 1959 (Qld) s 61JB; Forest Rights Registration Act 2000 (Tas) s 5.

116 Forest Property Act 2000 (SA) ss 7, 12; Climate Change Act 2017 (Vic) s 4(2); Carbon Rights Act 2003 (WA) s 6.

117 Sharon Christensen et al, 'Issues in Negotiating a Carbon Sequestration Agreement for a Biosequestration Offsets Project' (2013) 21(3) Australian Property Law Journal 195, 196.

118 Cf Carbon Rights Act 2003 (WA) s 12; Hepburn (n 70) 251-2. Commercial agreements can only be registered if they are in a prescribed form, and with the consent of registered mortgagees and freehold owners. In South Australia and Western Australia, for example, these contracts must: be in writing; include a statement advising the contract is made under the relevant act; and include essential information such as the identity of the relevant land, the vegetation, and project duration, having the consent of all registered mortgagees and freehold owners: see Forest Property Act 2000 (SA) ss 6-7. Cf Carbon Rights Act (WA) s 5(2); Transfer of Land Act 1893 (WA) s 104B(1)(a).

119 A conservation covenant may be entered into by a landowner and public authority to conserve or protect part or all of the relevant land, support biodiversity, conserve land, soil, or native vegetation, or protect wildlife: see National Parks and Wildlife Act 1974 (NSW); Biodiversity Conservation Act 2016 (NSW) s 1.3; Nature Conservation Act 1992 (Q1d) s 4; Native Vegetation Act 1991 (SA); Nature Conservation Act 2002 (Tas) s 34; Victorian Conservation Trust Act 1972 (Vic) s 3; Conservation, Forests and Lands Act 1987 (Vic) s 4; Soil and Land Conservation Act 1945 (WA). Notably, under the Biodiversity Conservation Act 2016 (NSW) s 1.3(d), covenants can be used specifically to support biodiversity conservation in the context of climate change.

120 National Parks and Wildlife Act 1974 (NSW) s 69F(1)(b); Biodiversity Conservation Act 2016 (NSW) s 5.24; Nature Conservation Act 1992 (Qld) s 134; Native Vegetation Act 1991 (SA) s 23B; Nature Conservation Act 2002 (Tas) s 38; Victorian Conservation Trust Act 1972 (Vic) s 3A(11); Conservation, Forests and Lands Act 1987 (Vic) s 72; Soil and Land Conservation Act 1945 (WA) s $30 \mathrm{~B}$. 
of an ERF project or CMO appears similar to the notification systems used by both the Torrens system, and under state forestry or land conservation laws. However, unlike these mechanisms, the Carbon Credits Act entries are not clearly supported by an analogous interest in land, or a provision deeming them to be a particular interest in land. As a result, they provide an unreliable indication of the nature of the rights and obligations arising from ERF projects. This illumines a broader issue of misalignment between a federal regime to address climate change, and statebased real property systems of land title. In this regard, there is a significant opportunity to better integrate the ERF Register with the existing Torrens Registers to improve the effectiveness of both regimes.

While it might be argued that by failing to articulate how ERF projects and CMOs relate to existing property law, the Carbon Credits Act reflects growing acceptance that the social obligations with which it deals are inherent in ownership and require no special treatment. However, this uncertainty will likely create confusion due to misaligning how ERF project and CMO interests and obligations are described in the property law system, compared to those which are better defined under forestry and land conservation laws. Perhaps a better argument is that although there is no problem with imposing obligations (even onerous obligations) on landowners in order to achieve a desired purpose, it is critical however to think carefully about the way in which those obligations are imposed in light of existing modes of ownership (ie, how people actually find out information about their land and what they can do with it). Failure to do so may reduce the effectiveness of the scheme overall. Of course, that has to be balanced against the fact that if the trees have released all their carbon, the mitigating effect of the project would be rendered otiose.

\section{Aligning the Classification of Climate Change Rights and Social Obligations under Climate Change and Property Laws}

Australian laws relating to climate change classify the rights and social obligations arising from emissions mitigation projects in relation to land in different ways, including (as we have seen in relation to the Carbon Credits Act) failing to classify them in relation to land at all. This poses a substantial challenge for Australia's system of land title. Not only does this create uncertainty about the nature of rights and obligations that are registered against the title to land used for such projects (Part III(B)), but it also generates conflict about whether, and to what extent, these rights and obligations bind successors in title and take priority over other registered and unregistered interests in land (Part III(D)).

'Forestry rights' is the umbrella term used to describe a right to carbon sequestration, ${ }^{121}$ as well as a right to engage with incidental matters including land access, land management, and tree maintenance. While academic attempts to characterise the right to carbon sequestration as a common law or equitable profit

121 Conveyancing Act 1919 (NSW) s 87A; compare 'forest product' with 'natural resource product' in the Forest Property Act 2000 (SA) s 3A; Forest Rights Registration Act 2000 (Tas) s 3; Climate Change Act 2017 (Vic) s 3; Carbon Rights Act 2003 (WA) s 3; Hepburn (n 70) 248-9. 
à prendre or conservation easement have been unsuccessful, ${ }^{122}$ these rules have been avoided by forestry laws that recognise carbon sequestration rights by deeming or verifying them as interests in land, although neither approach provides a perfect solution. For example, in New South Wales, Queensland, and Tasmania, forestry laws deem a carbon sequestration right to be a profit à prendre. ${ }^{123}$ Despite the 'appeal of familiarity', 124 the 'non-standard character of the carbon right' makes it an 'uneasy fit' ${ }^{125}$ with the essential characteristic of this interest, namely, the difficulty of construing carbon sequestration as taking a natural product from land. ${ }^{26}$ In contrast, South Australian, Victorian, and Western Australian forestry laws recognise carbon sequestration rights as novel proprietary interests, ${ }^{127}$ which avoids the need to compromise or qualify common law rules about the creation of specific proprietary interests. ${ }^{128}$ In Victoria, a carbon sequestration right is expressly recognised as an unspecified interest in land, ${ }^{129}$ in order to enable it to be recorded under 'catch-all' provisions of the Transfer of Land Act 1958 (Vic). ${ }^{130}$ Incidental rights for land access, land management, and tree maintenance receive the same classification as carbon sequestration rights under the laws of relevant states.

Despite there being parallels between carbon sequestration rights and CMOs under the Carbon Credits Act with rights recognised by forestry laws, and obligations enforced by conservation covenants, the nature of rights and obligations affecting land under the Carbon Credits Act remains unclear. In this respect, rights and obligations under the Carbon Credits Act are misaligned with similar rights and obligations that appear under both forestry and environmental and biodiversity laws. The lack of any provisions in the Carbon Credits Act to clarify the nature of these rights and obligations in land may be explained, in part, by the legislative history of the Carbon Credits Act. Between 2012 and 2014, the Carbon Credits Act applied only to land-based emissions offset or sequestration projects, which could generate carbon units for entities liable for the carbon tax under the national Clean Energy Act 2011 (Cth), as repealed by Clean Energy

122 See O'Connor et al (n 57); Hepburn (n 70); Nicola Durrant, 'Legal Issues in Carbon Farming: Biosequestration, Carbon Pricing, and Carbon Rights’ (2011) 2(4) Climate Law 515.

123 Conveyancing Act 1919 (NSW) s 87AB; Forestry Act 1959 (Qld) s 61JB; Forest Rights Registration Act 2000 (Tas) s 5.

124 Hepburn (n 70) 263, citing Steven A Kennett, Arlene J Kwasniak and Alastair R Lucas, 'Property Rights and the Legal Framework for Carbon Sequestration on Agricultural Land' (2005) 37(2) Ottawa Law Review 171, 208.

125 Hepburn (n 70) 256, 261-2.

126 Clos Farming Estates Pty Ltd v Easton (2002) 11 BPR 20,605, 20,617-8 [62] (Santow JA); ibid.

127 Forest Property Act 2000 (SA) ss 7, 12; Climate Change Act 2017 (Vic) s 4(2); Carbon Rights Act 2003 (WA) s 6.

128 Hepburn (n 70) 245.

129 Climate Change Act 2017 (Vic) s 4(2). Note under the former Climate Change Act 2010 (Vic), as repealed by Climate Change Act 2017 (Vic) s 98, and Forestry Rights Act 1996 (Vic) ss 4, 14-15, as repealed by Climate Change Act 2017 (Vic) s 75, carbon sequestration rights were regarded as personal choses in action arising from forestry agreements.

130 See, eg, Transfer of Land Act 1958 (Vic) s 88B(2). Note at s 88B(3) confirms that recording of the interest in title does not affect the nature of the underlying rights. 
Legislation (Carbon Tax Repeal) Act 2014 (Cth). ${ }^{131}$ As required by the then current Carbon Credits Act (since heavily amended), not only did a proponent have to own a carbon sequestration right in land before being eligible to receive carbon credits under the Act, but that right had to also arise from the proponent owning a registered legal estate or interest in that land, or pursuant to another agreement which was recorded on the Register. ${ }^{132}$ According to O'Connor et al, this effectively required a proponent to have the legal or functional characteristics of a registered owner of project land. ${ }^{133}$ In practice, this limited the range of eligible proponents to those which would also hold carbon sequestration rights under a state forestry scheme. ${ }^{134}$

Importantly, this is no longer the case, as under the current version of the Carbon Credits Act a proponent may, but is not required to, own a registered legal estate or interest in land. ${ }^{135}$ Owners of legal estates or interests in project land are now defined as 'eligible interest holders' ${ }^{136}$ Accordingly the role played by a proponent under the former Carbon Credits Act, is now played by a proponent who has obtained consent to carry out the project from eligible interest holders. Thus, ownership of land and the ability to carry out a project has been severed. Consequently, while the Carbon Credits Act and state forestry laws both relate to carbon sequestration projects, the schemes they administer are entirely independent. In this respect, owners of rights and obligations arising under the Carbon Credits Act cannot rely on the classification given to similar rights and obligations that might be recognised under forestry or environmental and biodiversity laws in order to secure their interests as an interest in land, or fulfil the preconditions required to record or register that right or obligation on the Register.

While the operative effect of all three legislative schemes may appear similar, to modify how landowners can exercise their ownership rights for long periods in time in order to achieve environmental objectives, the Carbon Credits Act lacks the provisions otherwise contained in the other laws to clarify the proprietary consequences of modifying ownership in this way. While this could be addressed by amending the Carbon Credits Act, it also raises questions about how Australia's real property laws - including Torrens statutes - could be improved to better accommodate changing views of land ownership. Accordingly, while our understanding of the true operation of ownership is evolving in light of the obligations related to attempts to address climate change, proponents, owners, and occupiers of land used for ERF projects may be uncertain about the extent and

131 Clean Energy Act 2011 (Cth), as repealed by Clean Energy Legislation (Carbon Tax Repeal) Act 2014 (Cth); Australian Government, Securing a Clean Energy Future: The Australian Government's Climate Change Plan (Report, 2011) 91-4.

132 Carbon Credits Act ss 27, 43, as amended by the Carbon Credits (Carbon Farming Initiative) Amendment Act 2014 (Cth).

133 O'Connor et al (n 57) 406.

134 Explanatory Memorandum, Carbon Credits (Carbon Farming Initiative) Bill 2011 (Cth) 28. See further Durrant (n 122) 521.

135 Carbon Credits Act $\mathrm{s} 5$ defines project proponent as an entity that is responsible for, and has the legal right to, carry out the project.

136 Ibid ss 43-4. 
nature of these obligations. This is not ideal and the unsettled position of proponents and landowners may cause conflict while the ERF project is on foot. More importantly, changes to ownership will lead to conflict between successors in title to these parties. Such individuals are likely not to have been involved in the original ERF transaction, but are nonetheless bound by the obligations arising from it during the permanence period.

\section{Rights Arising from Climate Change Mitigation Projects and Their Obligations: Consequences for Successors in Title}

The failure of the Carbon Credits Act to accommodate ownership in relation to ERF projects, permanence periods, and CMOs, poses significant risks to nonproponent owners of project land and their successors in title. While state forestry and environmental laws provide a mechanism to record and register interests arising from carbon sequestration projects and land conservation works on title (with the effect that they become binding on successors in title), this is not the case for ERF projects, permanence periods, and CMOs under the Carbon Credits Act. Conversely, no mechanism exists within Torrens statutes for proponents to otherwise record the existence of ERF projects. Accordingly, although rights and obligations arising from the existence of ERF projects will apply to land throughout the permanence period by virtue of the Carbon Credits Act, nonproponent owners and their successors in title may find themselves unaware of the consequences that these rights and obligations have on their ownership, but will nonetheless be bound to abide by their terms and conditions.

As introduced above, if the proponent does not also own the fee simple estate in project land, they are expected to obtain consent from owners that hold an 'eligible interest' in project land, such as the owners of registered estates and interests in land, including for example, the holder of the fee simple, leasehold and security interests. ${ }^{137}$ By providing consent, the rights and obligations arising under the Carbon Credits Act will bind the owners of these eligible interests. However, the knowledge of what they are actually agreeing to, and the detail provided to those interest holders considering giving consent, is questionable. Eligible interest holders provide consent by signing a document that identifies key information about the ERF project, such as the duration of the permanence period. ${ }^{138}$ However, the consequences of these arrangements, specifically the possible liability of owners (and occupiers) of land to fulfil CMOs until the permanence period ends, are only referred to as unilateral acknowledgements or declarations. ${ }^{139}$ The position of entities that occupy project land pursuant to an unregistered lease ${ }^{140}$ or contractual licence arrangements is particularly perilous. While these entities may

137 Ibid. Similar conditions apply to Crown land: at s 45, and native title land: at s 45A. Cf ibid s 5, as repealed by Carbon Credits (Carbon Farming Initiative) Amendment Act 2014 (Cth), under which a proponent must hold a carbon sequestration right before their project would be eligible to receive carbon credits.

138 Clean Energy Regulator, 'Eligible Interest Holder Consent' (Form No CER-ERF-EIH001, 23 June 2015).

139 Ibid 8

140 For example, Transfer of Land Act 1958 (Vic) s 66 prohibits registration of a lease with a term of less than three years. In states such as Victoria, creation of leases does not require registration. 
be held liable for the satisfaction of a CMO by virtue of being an 'occupier' of land for the purpose of Carbon Credits Act section 97(10), the basis for their occupation may not be an estate or interest that makes them an 'eligible interest holder' that might have given consent to the transaction. In this respect, owners and interest holders who have not undertaken an ERF project must ensure they understand the obligations that may be imposed on them under the relevant scheme, and take care to address liability for ongoing obligations with the proponent as part of their contractual arrangements, ${ }^{141}$ whether or not they have been asked to consent to the project.

The potential adverse consequences of this arrangement for ownership is also illuminated by transactions involving carbon offset providers. The ERF Register identifies that a range of carbon sequestration projects have already been implemented for the purpose of generating emissions offsets for airlines, manufacturers, energy suppliers, and travel companies in order to achieve, for example, 'carbon neutral' certification under the government's 'Carbon Neutral Program'. ${ }^{142}$ Companies such as Greenfleet have planted more than 8.9 million native trees in more than 475 forests across Australia and New Zealand. However, while corporations approach Greenfleet for the purpose of creating emissions offset opportunities, ${ }^{143}$ Greenfleet also actively seeks opportunities to revegetate private and agricultural land at 'no cost' to landowners. ${ }^{144}$ This 'mixed use' may appeal to landowners who seek to maximise the use of fallow land, to prevent erosion, or desire other commercial or environmental purposes. ${ }^{145}$ For example, as illustrated by a Greenfleet testimonial regarding 'Long Flat' farm in Lismore, New South Wales:

We purchased 20 acres of overgrazed dairy farmland. When I first arrived, there were two trees on 20 acres. We had 15 acres on the floodplain that we weren't quite sure what to do with, so I asked Greenfleet to work with us. With their assistance we planted over 5,500 trees on our property. By partnering with Greenfleet, the carbon agreement on title guarantees these trees are around long after I'm gone. ${ }^{146}$

While owners appreciate the long-term nature of their commitment and, in cases such as the above, that their land title may be updated to reflect the commitment made, it is unclear whether owners understand the legal consequences of this decision. In this situation, it is unclear what liability the offset provider may have if a carbon reversal event occurs during the permanence period. Unless the contract between the owner and offset provider specifically addressed this

141 Christensen et al (n 117) 226.

142 Commonwealth of Australia, National Carbon Offset Standard for Organisations (Report, 1 November 2017) 6. A list of certified business can be viewed at 'Carbon Neutral Certified Organisations, Products and Services and Events', Department of the Environment and Energy (Web Page)

$<$ http://www.environment.gov.au/climate-change/carbon-neutral/carbon-neutral-program/certifiedbusinesses $>$. See also Intrepid Group, Communication on Progress Report 2016 (Report, 2016) 19-20.

143 'About Greenfleet', Greenfleet (Web Page) <http://www.greenfleet.com.au/About-us/About-Greenfleet>.

144 'Partner with Greenfleet to Revegetate your Land', Greenfleet (Web Page) $<$ http://www.greenfleet.com.au/Landowners $>$.

145 APN House et al, 'Integrating Production and Natural Resource Management on Mixed Farms in Eastern Australia: The Cost of Conservation in Agricultural Landscapes' (2008) 127(3-4) Agriculture, Ecosystems \& Environment 153; Williams, 'Cost-Effective Landscape Revegetation' (n 76). 
eventuality, a landowner may need a court's assistance to obtain compensation, if it is in fact available, from the offset provider. It is not immediately apparent what source of law a landowner may rely on to do so. If there is nothing in the contract, contract law is unlikely to provide a remedy. If the reversal event was not as a result of negligence, the law of torts will similarly be unable to help. If the law is silent on what is to happen in these circumstances a landowner may be in an invidious position.

In this respect, both conservation covenants under state environmental protection and biodiversity conservation laws, and entries/notations under the Carbon Credits Act, reflect social obligations that may affect landowners for long periods of time, and this presents real risks for landowners in relation to inflexibility, resource conflict, and loss of income/future land development potential. ${ }^{147}$ While data taken from interviews with conservation covenantees indicates that compensation by way of government rebates and access to GHG emissions trading or credit schemes offset the long-term loss of use or enjoyment for the benefit of conservation, ${ }^{148}$ it is unlikely that covenantees will also be able to benefit from compensation by way of carbon credits under the Carbon Credits Act due to 'additionality' requirements. ${ }^{149}$ For example, in the case of the revegetation of 'Eastlake', Williams explained that approximately 80 per cent of funding received for plantings was provided by land care conservation and local land services grants. ${ }^{150}$ If conservation covenants have been entered into in exchange for these grants, this would likely exclude the relevant parts of Eastlake from being the location for projects otherwise eligible for ERF support. Commentators are keen to highlight the importance of addressing the financial burden of these obligations as part of commercial arrangements for forestry and carbon sequestration projects. ${ }^{151}$ Consequently, decisions made by a proponent in order to access funding provided by the ERF, or in relation to conservation covenants, have long-term ramifications for land use restrictions, not only on them as the current fee simple owner, but also successors in title while the permanence period applies.

Parties intending to deal with the freehold estate in land subject to conservation covenants, forestry carbon rights, or ERF projects must also be made aware of the obligations that they adopt upon acquisition of a freehold estate in land. While in many cases parties will be able to discover that obligations exist by searching the Register (Part III(B) above), in relation to ERF projects in particular, the Registrar may have not exercised its discretion to make notations or entries, and thus the project's existence (or prior existence) may not be discovered. Alternatively, the Registrar may have exercised its discretion to remove an entry about the existence of an ERF project once the project term was complete, notwithstanding that a

147 Philippa England, 'Conservation Covenants: Are They Working and What Have We Learned?' (2015) 34(1) University of Tasmania Law Review 92, 98-102.

148 Katie Moon and Chris Cocklin, 'Participation in Biodiversity Conservation: Motivations and Barriers of Australian Landholders' (2011) 27(3) Journal of Rural Studies 331, 339. See also ibid 101.

149 Carbon Credits Act s 27(4A).

150 Williams, 'Cost-Effective Landscape Revegetation' (n 76) 466, 468.

151 Christensen et al (n 117) 226. 
permanence period remained on foot. Notably, a key information statement made by the Regulator about permanence confirms that 'there are currently no notices on land titles for Emissions Reduction Fund projects'. ${ }^{152}$ Without entries of any kind under the Carbon Credits Act being made on the Register, it is difficult to see how any entity would reasonably discover the possible impact that the Carbon Credits Act might have on land ownership now or in the future.

Despite uncertainty as to whether interests in ERF projects created by the Carbon Credits Act are proprietary, it is arguable that in the context of a sale to a successor in title the vendor has an obligation to disclose the existence of an ERF project while a permanence period applies, ${ }^{153}$ in order to fulfil its statutory obligations in relation to the sale of land. ${ }^{154}$ As noted above, the Regulator regards the public ERF Register of projects as 'a point of reference' for people intending to deal in land. ${ }^{155}$ However, as the ERF Register is separate to the Torrens Register, and the mechanism included in the Carbon Credits Act to enter or note the existence of ERF projects on the Torrens Register is discretionary, a prospective purchaser must search both registers to obtain a full understanding of any potential obligations or liabilities under the Carbon Credits Act. This also relies on a proponent understanding the impact of the ERF project on land ownership - it is one thing for a proponent to appreciate that the carbon contract entered into with the Regulator to establish an ERF project affects land during the project term, but another for a proponent to appreciate that such impacts may continue long after an ERF project is complete. In this regard, due diligence is important to ensure land can be used in the particular ways that the purchaser expects as in the incoming proprietor. Generally speaking, the principle of caveat emptor applies to all purchases of real property. ${ }^{156}$ Consider our hypothetical example: Proponent A, instead of undertaking the revegetation project itself, engaged an Offset Provider to carry out the project. As the fee simple owner, Proponent A consented to the project as an 'eligible interest holder'. The Offset Provider manages the land and maintains the trees until the project is completed in 2050. In 2051, Proponent A sells its land to a Purchaser. Despite completing all the usual searches as part of due diligence, the Purchaser's lawyer finds no record to indicate the existence of an ERF project on the land, or a CMO. A bushfire in 2060 damages or destroys all of the trees. Assuming that neither the Offset Provider nor Proponent A restores the carbon sequestration to benchmark levels or relinquish carbon credits, the

152 Clean Energy Regulator, 'The Emissions Reduction Fund and Permanence on Land' (n 107) 2.

153 Vanessa Johnston, 'Rights and Interests in Land Created under the Carbon Credits Act 2011 (Cth)' (2016) 25(3) Australian Property Law Journal 199, 217-8.

154 For example, Sale of Land Act 1962 (Vic) ss 32, 32C-32D.

155 'Emissions Reduction Fund Project Register' (n 89).

156 Sir Alexander Kingcome Turner and Richard John Sutton, The Law Relating to Actionable Nondisclosure and Other Breaches of Duty in Relations of Confidence, Influence and Advantage (Butterworths, $2^{\text {nd }}$ ed, 1990) 135 [7.19]:

The modern view, from which no substantial divergence appears either in the text or in reports of recent cases, is that the doctrine of caveat emptor must prevail when the complaint of the purchaser is exclusively one going to the quality of the land sold, or to the use to which that land may be put, or that owing to non-disclosed fact within the knowledge of the vendor its value will be less than what [they] had supposed. 
Regulator imposes a CMO on the land. As the owner, the Purchaser must take all reasonable steps to ensure that the sequestered carbon is restored to the benchmark level under the Carbon Credits Act, despite having no knowledge of the existence of the ERF project, nor any contractual relationship with the Offset Provider who had the legal right and responsibility to carry out the project.

In this situation, the failure of the Carbon Credits Act to address land ownership may lead to conflict between the vendor and purchaser in relation to the conveyance of fee simple estates. If settlement has already occurred, the Purchaser may have limited avenues to 'unwind' the transaction unless it could be argued that failure to disclose the existence of a completed ERF project and existing permanence period is fraud. Moreover, if there has been long delay between the sale and the imposition of a CMO, limitation periods will also come into play, potentially leaving a new owner, perhaps several times removed, with no remedy at all. On this premise, the failure of the Carbon Credits Act to accommodate ownership leads to circumstances that have been previously described in authorities as 'subversive', ${ }^{157}$ and which undermine the objectives of the Torrens system. Entities dealing with property may have a responsibility to become more aware of potential obligations that could affect land arising from climate change and the Carbon Credits Act, and there is always a risk that a party may not, whether or not in good faith, disclose the existence of these obligations in the course of a transaction. Nonetheless, the risk of this occurring is heighted by the way that the Carbon Credits Act relates to the Torrens system and to ownership, and which could be reduced by considering ownership in ways illustrated by state forestry and environmental laws. More generally it raises a broader issue. While it is clear that the Carbon Credits Act imposes obligations on landowners, and that those obligations can continue for a long time, it is important that these obligations can be identified with certainty. Although the counter-traditions of property within the Western tradition indicate that obligation is an intrinsic aspect of land ownership, this does not mean owners should be saddled with obligations of which they were unaware and where lack of awareness was a result of either another person's fault, or a defect in legislative drafting, or another failure of real property laws to accommodate these emerging issues. Recognising that land ownership entitles obligation is only the first step, necessary obligations must then be carefully integrated into the existing body of law in order to achieve the desired effect. Failure to do so may work unfairness and may ultimately lead to the overall aims not being achieved.

\section{CONCLUSION}

Responses to climate change that directly affect land provide a key example through which to explore and illustrate how counter-traditions based on obligation and responsibility operate within the existing Western liberal tradition of ownership as it relates to land. In Australia, current land use trends and the relative 
low price of GHGs means that it is likely that land-based activities involving carbon sequestration will continue to form a significant proportion of the initiatives undertaken to reduce GHG emissions in line with domestic and international targets. This provides significant opportunities for private landowners to voluntarily bring land within the scope of the Carbon Credits Act by implementing such projects. By doing so, the rights of subsequent landowners will be impacted for the duration of any permanence period, should the original proponent fail to comply with their statutory obligations during that time.

This article has analysed how such obligations and responsibilities to care for and tend to land are recognised by Australian law, and are reflected in the Carbon Credits Act, state forestry laws, and laws that generally promote environmental protection and biodiversity conservation. While this indicates that land ownership is flexible enough to contribute towards environmental objectives including climate change, problems arise when the impact of these laws on ownership are not fully considered, and tension is created between climate change laws and existing doctrines of real property law. This article has discussed three such problems in detail, including: the design of mechanisms intended to notify parties of rights and obligations associated with ERF projects; the treatment of these rights and obligations in the context of recognised proprietary estates and interests in land; and the potential impact of these rights and obligations on successive owners or occupiers. Comparing and contrasting relevant design features of the Carbon Credits Act, state forestry laws, and laws that promote environmental protection and biodiversity conservation illuminates that the operative effect of each in relation to modifying land ownership is very similar. However, in comparison to the other schemes, the Carbon Credits Act lacks the provisions that are necessary to clarify the proprietary consequences of modifying ownership in this way. This has significant implications for land ownership as we currently understand it. There is significant risk of conflict arising between owners of relevant estates and interests in land if the tension between Australia's Carbon Credits Act, property law doctrines, and statutory regulations is not resolved. It is not only a matter of recognising how the Carbon Credits Act deals with land ownership, but recognising how real property laws, including the Torrens statutes, accommodate land in the context of climate change. Resolving this tension is essential for the development of both environmental and property law regimes that have the greatest prospect of achieving their respective objectives, and helping with efforts to mitigate the most severe outcomes that may accompany our changing climate. 